\title{
A Simple Corer Set inside an Ekman Grab to Sample Intact Sediments with the Overlying Water
}

\author{
Hisashi Yokoyama ${ }^{1)}$ and Hiroshi Ueda ${ }^{2)}$ \\ ${ }^{1)}$ National Research Institute of Aquaculture \\ ${ }^{2)}$ Nakajima Marine Biological Station, Ehime University
}

\begin{abstract}
A simple coring device was designed for obtaining surface sediments and the overlying, near-sediment-surface water in lakes and shallow marine bays. It consists of a removable corer tube and valve attached to the inside wall of an Ekman grab by a clamp. The device has several advantages as follows: 1) core samples can be obtained with minimal disturbance to the sediment-water interface; 2) samples can be successfully collected even from sandy bottoms; 3 ) it can be easily operated even from a small boat.
\end{abstract}

Key words: corer, core sampler, Ekman grab, sediment-water interface

\section{INTRODUCTION}

Various coring devices have been used to obtain bottom sediments (McIntyre \& Warwick 1984). Earlier hand-held gravity corers, which by their own weight fall through the water column and penetrate the sediment, generally have two major disadvantages: 1) disturbance to the surface sediments by their downwash and impact at the time of landing, and 2) the loss of sandy sediments from the tube end during ascent. Bácescu (1957) reported a grab with a built-in core tube, but his sampler is large, intricate, and not suitable for sectioning the sediment subsamples and also for sampling the overlying water. We describe a sampler that overcomes these problems by using a simple, remountable tube which is set inside an Ekman grab.

Received July 14, 1997 : Accepted October 27, 1997

\section{CONSTRUCTION}

The sampler is designed to allow a core tube to be attached by a clamp to the inside wall of an Ekman grab which covers an area of $0.04 \mathrm{~m}^{2}$. The core tube can be made of pipes of various diameters. We constructed tubes of an internal diameter of $4.4 \mathrm{~cm}$ and a length of $23 \mathrm{~cm}$ (Fig. 1A, B) from transparent acrylic cylinder, and a square pipe with sides of $5 \mathrm{~cm}$ (Fig. 1C). The square tube is particularly suitable for visual inspections and photography. The lower edge of the tube is sharpened to facilitate penetration. The upper end of the sampler is shown in Fig. 2. The valve (a), which has a diameter slightly larger than the external diameter of the tube, is connected to the top of the tube by a rubber hinge (b). Another type of valve (a'), which is attached to the tube with a rubber band (c), is removable for convenience of sample extraction. The valves are made of a rubber stopper (a) and a plastic plate (a'), respectively. A string with a loop at the end (d) is connected to a projecting screw (e) on the 


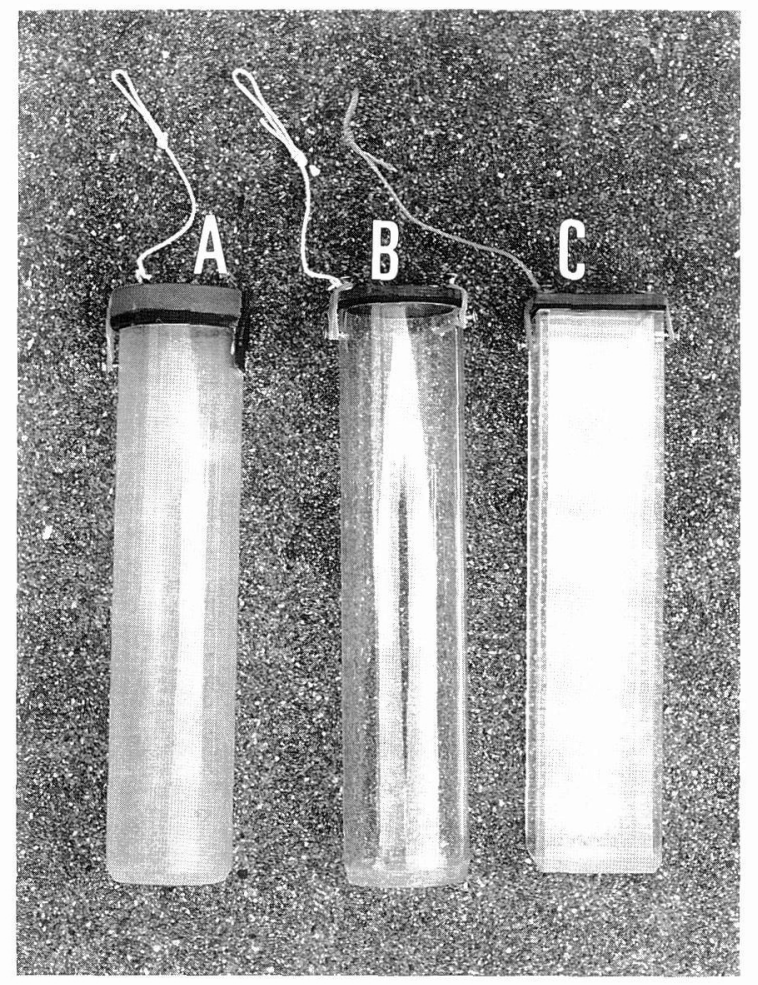

Fig. 1. Core tubes. A, a tube with a valve connected by a hinge. $\mathrm{B}$, a tube with a removable valve. C, a square tube.

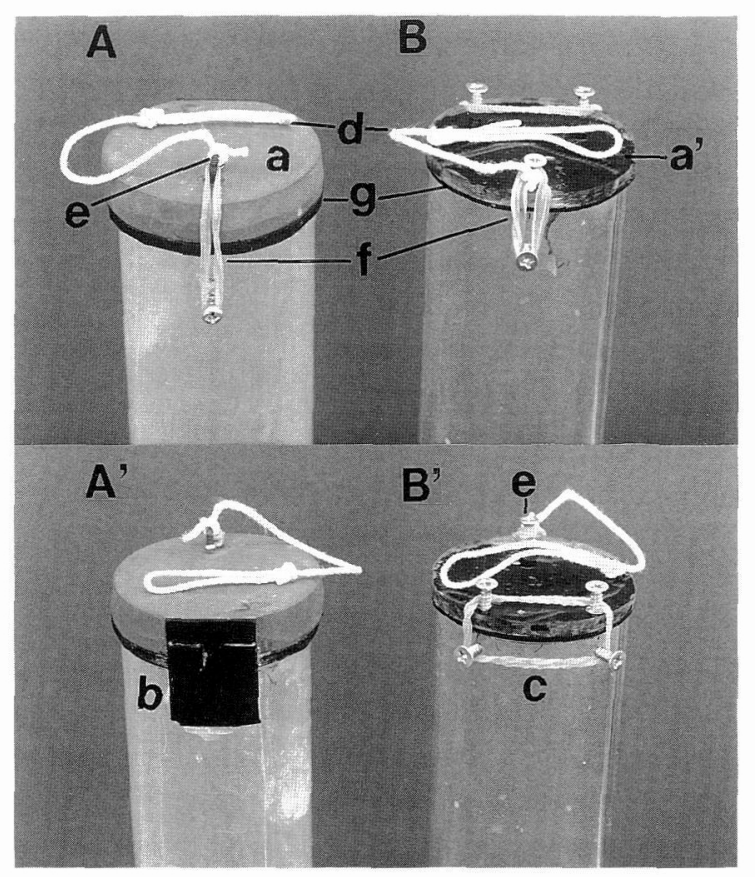

Fig. 2. The upper end of the tube. A, a tube with a valve connected by a hinge. $B$, a tube with a removable valve. A' and B', reverse sides of A and B, respectively. See text for explanations of a-g. upper side of the valve. A rubber band ( $\mathrm{f}$ ) is hooked between the screw on the valve and a screw on the side of the tube. Rubber packing (g) is glued onto both the lower side of the valve and the upper edge of the tube to prevent leakage when closed. A clamp (Fig. 3, h) is fixed to the inside wall of the grab box by a nut.

\section{SAMPLING OPERATION}

The procedure for sampling is first to open the top of the grab and second to set the core tube vertically in the grab box using the clamp (Fig. 3). The valve is held in the open position by hooking the loop of the string to the latch (Fig. $3, \mathrm{i})$ of the trip mechanism, which is activated by the messenger. The open valve allows water displacement and penetration of the sediment. The sampler should be lowered slowly to the bottom to ensure minimal disturbance of the

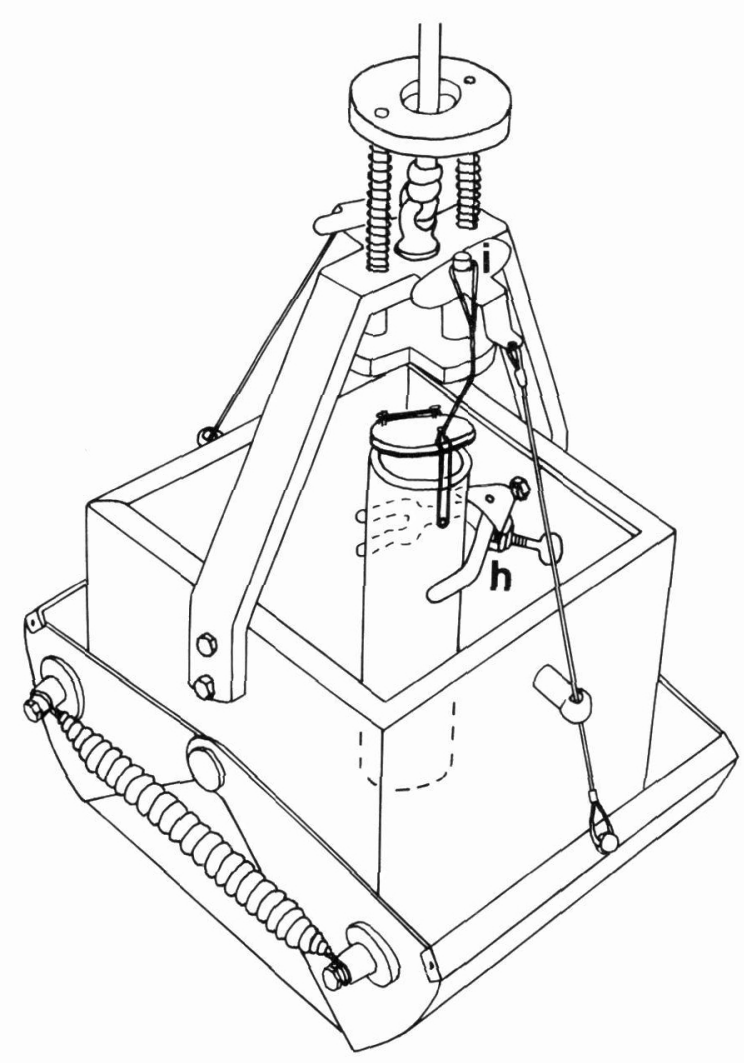

Fig. 3. An Ekman grab with a core tube attached ready for sampling. See text for explanations of h-i. 
surface layer of the sediment. The sampler penetrates vertically into the sediment under the weight of the Ekman grab (weight added to give a total weight of $13 \mathrm{~kg}$ ). In soft sediments, the corer penetrates to about $10 \mathrm{~cm}$; in harder, sandy sediments, it penetrates to about $4 \mathrm{~cm}$. A messenger for the grab is sent down the line to operate the trip mechanism. The messenger simultaneously closes the bottom of the grab by the two opposed, pivoting plates and also the valve of the corer by releasing the string and via the contraction of the rubber band. After the sampler is hauled aboard, the tube is stoppered at the lower end and removed by loosening the screw of the clamp. The water in the tube can be siphoned off and stored for chemical analysis. The sediment is removed from the tube using a piston. The sediment is brought to the upper end of the tube and sliced into separate subsamples. Thinner sections of the sediment can be obtained by freezing and then slicing the sample.

\section{DISCUSSION}

The new device has the following advantages. (1) Sediment cores with the overlying water can be obtained with minimal disturbance to the sediment-water interface. Most of the earlier handy models are hard to use without disturbance of the sediment-water interface. The present system enables the vertical positioning of the core tube without noticeable disturbance by lowering the sampler gently onto the bottom. For example, intact animal burrows and epibenthic meiofaunal organisms in their natural positions in and on the sediment were observed in core samples obtained from Gokasho Bay (water depth, 20 m) (Fig. 4). The clear overlying water collected immediately after the sampling and needle-shaped shells of rhizamminid foraminiferans projecting into the water indicate the suitability of this device. (2) Samples can be successfully collected even from sandy bottoms. Coring on sand is difficult with a simple device, therefore a sediment retention mechanism is usually required to prevent loss of the sample during ascent. The present system proved satisfactory under all conditions where the Ekman grab is effective. (3) The

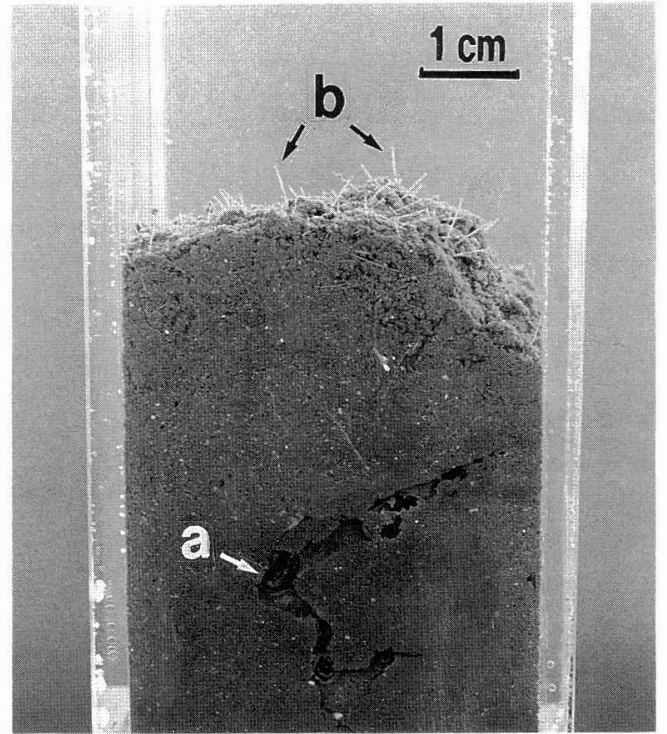

Fig. 4. A core sample with intact sediment-water interface inside. Burrows of infaunal macrobenthos (a) and epifaunal meiobenthic rhizamminid foraminiferans (b) are visible.

sampler is light and compact. It can be operated by a single person from a small boat in the same manner as the operation of an Ekman grab. (4) The core tube is exchangeable with tubes of differing diameter or shape. This allows a greater choice to suit the objectives of the investigation. The ease of removal of the core tube also enables us to bring the sample in the tube to the laboratory as it is and continue to observe it. (5) The corer is easy to construct with inexpensive and readily available materials.

The ability to readily collect undisturbed core samples from a variety of substrata will certainly contribute to biological, bacteriological, and chemical studies of processes taking place at the sediment-water interface.

\section{REFERENCES}

Bácescu, M., 1957. Apucătorul-sondă pentru studiul cantitativ al organismelor de fund - un aparat mixt pentru colectarea simultană a macro-şi microbentosului. Buletinul Institutului de Cercetări Piscicole, 16: 69-82.

McIntyre, A. D. and R. M. Warwick 1984. Meiofauna 
techniques. In, Methods for the Study of Marine Benthos, Holme, N. A. and A. D. McIntyre (eds.), Blackwell Scientific Publications, London, pp.217244.

\section{Address}

Hisashi Yokoyama (reprint request): National Research Institute of Aquaculture, Nansei, Mie 519-01, Japan.

Hiroshi Ueda: Nakajima Marine Biological Station, Ehime University, Nakajima, Onsen-gun, Ehime 791-45, Japan. 